UDC 348:272-74(437.311)"14"

CERIF: S149, H165, H220, H300

DOI: 10.51204/HLH_21106A

\title{
Veronika ONDRÁŠKOVÁ*
}

\section{LEGAL ASPECTS OF THE ROLE OF THE CORRECTOR OF THE CLERGY IN THE EARLY FIFTEENTH-CENTURY DIOCESE OF PRAGUE}

The paper focuses on the institution of the Corrector of the Clergy within the Diocese of Prague. This ecclesial administrative representative was a criminal judge who also oversaw the moral conduct of the clergy. The paper compares legal rules set by the Church for the clergy through synodical statutes and an actual enforcement of these duties by the Corrector. The paper analyses the judicial book covering the period from 1407 to 1410, examining the judge's approach to moral delicts (breach of celibate, etc.), which constituted the majority of the cases. Emphasis is given on the prescribed punishments.

Key words: Corrector of the Clergy. - Diocese of Prague. - Ecclesial judge. - The Lands of the Bohemian Crown. - Moral delicts. - Breach of Celibate.

\section{INTRODUCTION}

One of the key periods for setting the foundations of ecclesial judicial institutions was the course of the $14^{\text {th }}$ century. ${ }^{1}$ The representative offices were established even before this period by a delegation of bishop's judicial power onto deputies, which led to the foundation of institutions

* $\quad$ Master student in $6^{\text {th }}$ semester, Masaryk University, Faculty of Law, Czech Republic, veronikaondraskova3gmail.com

The paper is part of a student research project.

The article has been presented at the conference „Iustoria 2021: Law and Religion” held by the University of Belgrade Faculty of Law on March $25^{\text {th }}-27^{\text {th }}, 2021$.

1 Zdeňka Hledíková, Svět české středověké církve, Argo, Prague 2010, 204. 
such as officials, ${ }^{2}$ general vicarage, ${ }^{3}$ or the inquisition. ${ }^{4}$ Apart from these general representative institutions that had more or less all equivalent stature within other regions of Europe, ${ }^{5}$ the Diocese of Prague formed another judicial institution that bore no analogy within foreign territories. ${ }^{6}$ The institution established was the Corrector of the Clergy, founded by the first archbishop of Prague, Ernst of Pardubice (Arnošt $z$ Pardubic). The foundation of the office is often connected to administrative reforms and the endeavours of the archbishop to correct the habits of the clergy, ${ }^{7}$ but it also had political causes. The Diocese of Prague was divided into ten archdeaconries ${ }^{8}$ that were managed by their representatives, who also administered some of the judicial power over their territories. At the time, the archbishop had very limited power over the naming of these archdeacons and the exercise of their duties. ${ }^{9}$ With the constitution of the Corrector of the Clergy, the archdeacons were submitted to a judge; meaning they had to report their visitations to the Corrector who, from then on, executed the judicial power over the clergy himself..$^{10} \mathrm{He}$ represented the archbishop, from whom he derived his authority. ${ }^{11}$ It is unclear to what extent did the archbishop interfere in the execution of his judicial power, although the preserved material suggests he was an initiator of some pardons or summons.

2 Ibid.

3 More in: Zdeňka Hledíková, Úrad generálních vikářoo pražského arcibiskupa $v$ době předhusitské, Prague 1971.

4 More in: Alexander Patschowsky, Die Anfange einer ständigen Inquisition in Böhmen, Walter de Gruyter, Berlin-New York 1975.

5 The institution of the official as well as the general vicarage had its roots in France. More in: Paul Fournier, Les officialités au Moyen Age. Étude sur l'organisation, la competénce et la competénce de tribunaux ecclésiastiques ordinaire en France de 1180 a 1328, Paris 1880. As to the foundation of the institution within the Diocese of Prague more in: Božena Kubíčková, K počátkům pražského oficialátu. Sborník př́spěvků $k$ dějinám hlavního města Prahy 5. Praha 1932, 391-479.

6 Zdeňka Hledíková, Korektoři kléru pražské diecéze. Právněhistorické studie 16, Academia, Prague 1971, 72.

7 Antonín Podlaha, Akta korektorů duchovenstva diecéze pražské z let 1407-1410, Sumptibus S. F. Capituli Metropolitani Pragensis, Praha 1921, 54.

8 Z. Hledíková, Svět české církve, 59.

9 Z. Hledíková, Korektoři kléru, 78. Cf.: At the time of the foundation of the office the appointment of Prague's archdeacon rested upon the Metropolitan chapter. Ivan Hlaváček, Zdeňka Hledíková, Vizitačni protocol pražského arcijáhenství pražského arcijáhna Pavla $z$ Janovic $z$ let 1379-1382, Academia, Praha, 1973, s. 10. However, in the analysed period (1407-1410) the appointment of the archdeacon has long since rested in the hands of the Czech archbishop.

10 Z. Hledíková, Korektoři kléru, 77-78.

11 Ibid. 
The Corrector of the Clergy (Corrector cleri civitatis et diocesis Pragensis) ${ }^{12}$ was overall a criminal judge who also supervised the moral conduct of the clergy. Although it was founded in the middle of the $14^{\text {th }}$ century, ${ }^{13}$ due to very limited source material, we are able to reconstruct the agenda of the office mainly from the beginning of the $15^{\text {th }}$ century, through one judicial book that has been preserved, collecting cases of the judge between the years 1407 and $1410{ }^{14}$ The office of the Corrector resided in Prague up to the Hussite revolution ${ }^{15}$ and unlike some of the other representative institutions, was not re-established after the turmoil. ${ }^{16}$ The office of the Corrector resided within the archbishop's palace in Prague, where the interrogations were conducted either in the prison cell or in the archbishop's palace. ${ }^{17}$ The trial conducted in front of the Corrector did not follow the traditional Roman canon tradition, but was shortened and consisted of summons, usually issued by the Corrector, or direct imprisonment of the cleric (in cases of theft, murder, but also probably recurrent breach of celibacy). The interrogation that followed was usually conducted under oath. In cases of moral delicts, the records also included a conditional punishment, in more severe cases the sentence was carried out in a separate record, sometimes on a different day than the original interrogation.

This paper analyses the preserved judicial book, focusing on moral delicts that were presented before the Corrector, and its legal aspects. The paper compares legal rules set by the Church at the local Synods ${ }^{18}$ with the real cases that ended up in front of the judge. The aim of the paper is to demonstrate the reality of the judicial institution and the approach it chose to follow in the question of punishing the clergy. The cases contained within the moral delicts were breach of celibate, unlawful visiting

12 Jan Adámek, Archiv český díl XLIII. Acta correctoris cleri civitatis et diocesis Pragensis annis 1407-1410 comparata, Centrum medivistických studií, Praha, 2018, XVII.

13 Jan Adámek, Korektor kléru arcidiecéze pražské jako trestní soudce, Sacri canones servandi sunt, Historický ústav AV ČR, Praha 2008, 343.

14 J. Adámek, Acta correctoris cleri, XVII.

15 More about their legal praxis in: Jiří Kejř, Výbor rozprav a studií z kodikologie a právních dějin, Masarykův ústav a Archiv Akademie věd České republiky, Praha 2012.

16 Only thanks to some records that were added later on are we able to reconstruct that the office continued after 1410, but because no other sources remain from the period after the Hussite revolution, it is believed that it was not re-established. Z. Hledíková, Korektoři kléru, 106.

17 As the archbishop's prison was under reconstruction.

18 The statutes issued at the synods were meant to correct the clergy and set punishments for the breach of the prescribed norms. They had to be in accordance with the general codifications of the Church, but could independently respond to situations in the Diocese and reflect the needed correctives. 
of taverns, playing dice or visiting brothels, etc. The paper also provides a graphical representation of the given punishments and time periods, and discusses the possible differences in the sanctions received, depending on the status of the cleric. The paper choses to examine the moral delicts (breach of celibacy and playing dice) because they form app. $46 \%$ of the $525^{19}$ cases recorded within the books. Within the judicial book of $1407-$ 1410 , the breach of celibate duty was the most common misdemeanour with 223 cases connected to it.

\section{MORAL DELICTS}

\subsection{A breach of celibacy}

The regulations enforcing celibacy among the clergy started to emerge during the $11^{\text {th }}$ century, ${ }^{20}$ although these endeavours reached Bohemia only later in the following centuries. The celibacy was later prescribed for all of the higher ordinations. ${ }^{21}$ These norms were proclaimed, among others, at the local synods via statutes that served as supplements to the general ecclesial codes. They were usually issued by bishops within individual dioceses and therefore reflected current issues and needs of the specific administrative unit. ${ }^{22}$

One of the first important norms connected to celibate and its enforcement can be found within the synodical statutes issued on the $15^{\text {th }}$ of June $1406 .{ }^{23}$ It contains an obligation for all the clerics to notify the corrector if they receive any information regarding concubinage or other crimes. According to that legal rule, if they do not comply with this obligation, they will be punished with prison or a fine. ${ }^{24}$ Despite this corrective, it was very rare for the clerics to tell on each other, although it also may have served as a distraction from one's own interrogation. For example, on the $12^{\text {th }}$ of July 1407, the Corrector of the Clergy questions a priest from Hvoždany, inquiring if he had held any women within his rectory.

19 J. Adámek, Acta correctoris cleri, XIV.

20 James A. Brundage, Law, Sex, and Christian Society in Medieval Europe, The University of Chicago Press, Chicago - London 1987, 249.

21 Paul Hinschius, System des Katoslichen Kirchenrechts mit besondere rucksicht auf Deutschland, Berlin 1895, 172.

22 Jaroslav V. Polc, Zdeňka Hledíková, Pražské synody a koncily předhusitské doby, Karolinum, Praha 2002, s. 13.

23 Ibid., 278.

24 „Item mandat omnibus decanis et plebanis ut concubinarios et usurarios et alios criminose viventes deferant ad correctores sub pena carcerali vel pecuniaria ad correctoris arbitrium irremissibiliter recipienda." In: J. V. Polc, Z. Hledíková, Pražské synody, 278. 
He answers under oath that he did not, but he believes that the tenant from Oslovo holds one. ${ }^{25}$ The book does not provide any further material on the mentioned tenant. Thus, the question remains - to what extent did the Corrector really enforce the prescribed norms?

The correct enforcement of the synodical statutes and surveillance of the moral conduct of priests was mainly within the scope of archdeacons, ${ }^{26}$ who had to report breaches and wrongdoers from within their unit. In order to observe how the priests carried out their administrative duties, the archdeacons issued visitations, based on which they reported the ills to the Corrector. ${ }^{27}$ Although some of the cases suggest that the investigation of the priests was usually incited by the archdeacons, ${ }^{28}$ others propose that sometimes not even the archdeacons fulfilled their duty thoroughly. An example may be drawn from a case from the $21^{\text {st }}$ of October 1409, where the Corrector interrogates a priest (Václav $z$ Jaroměre) on whether he had a concubine at his rectory. During the questioning, the Corrector finds out that the priest had a four-year lasting relationship and three children with the woman. When asked whether or not he already received any warning from his archdeacon for such behaviour - he replies that the archdeacon had not visited the rectory once in that time. ${ }^{29}$ The source does not provide any evidence about the interrogation of archdeacons, because, although they had to report the wrongdoers to the Corrector, they did not fall under his jurisdiction. It would have been within the power of a bishop to punish an archdeacon. They were subjected to criticism concerning the unscrupulous exercise of their duty prescribed by the synods even during the $14^{\text {th }}$ century. ${ }^{30}$ At the beginning of the $15^{\text {th }}$ century (15 $5^{\text {th }}$ of June 1407) the archbishop proclaimed that the breach of celibacy would be prosecuted under the punishment of privation of benefice, and

25 J. Adámek, Acta correctoris cleri, 37.

26 Before the office of the Corrector of the Clergy was established, it was within the scope of archdeacons to judge such moral lapses. An eloquent example was preserved through a visitation protocol of archdeacon Pavel $\mathrm{z}$ Janovic, who between the years of 1379-82 conducted a visitation of Prague's archdeaconry investigating breaches of ecclesiastical law. More in: Ivan Hlaváček, Zdeňka Hledíková, Vizitační protocol pražského arcijáhenství pražského arcijáhna Pavla z Janovic z let 1379-1382, Academia, Praha, 1973.

27 Z. Hledíková, Úrad korektora kléru, 79. Or the Corrector could have carried out the visitation himself. Ibid., 77.

28 J. Adámek, Acta correctoris cleri, 112, 123, 134.

29 Ibid., 453. Cf.: Although the time periods change, visitations were supposed to be carried approximately once a year. Ivan Hlaváček, Zdeňka Hledíková, Vizitační protocol pražského arcijáhenství pražského arcijáhna Pavla z Janovic z let 1379-1382, Academia, Praha, 1973, 17.

Z. Hledíková, Úrad korektora kléru, s. 79. 
he ordered all the archdeacons to subject acta visitacionum to the office of the archbishop under the punishment of excommunication. ${ }^{31}$ This regulation is not repeated again, although the archbishop mentions the prohibition of concubinage again in $1409 .{ }^{32}$ It remains uncertain whether the Church actually suffered any consequences due to this negligence.

Apart from the general obligation to notify the Corrector, the synodical statutes also mention a corrective regarding the breach of celibate duty, and prescribe a punishment. The relevant norm is mentioned in the first article of the statutes, ordering thusly:

"Item mandat omnibus clericus cujuscunque status ut concubinas de domibus ejiciant et de vicinatu cum effectu et sine mora sub pena excommunicationis et carcerali."33

Another very important source for this analysis is an article presented at a synod from 1406, which prescribes:

„...et concubinas de domibus et plebibus et de vicinatu ejiciant infra VI dies a notificatione praesencium sub pena carcerali perpetue sustinenda et sub aliis penis in statutis promulgatis." ${ }^{\text {" }}$

Since the synods occurred regularly at the end of the $14^{\text {th }}$ and the beginning of the $15^{\text {th }}$ century, the rule was often repeated, and the added punishment was set to withdrawal of benefice. ${ }^{35}$ The paper will now focus on the comparison of the highlighted aspects of the norm and the reality of the judicial praxis of the Corrector, paying particular attention to the status of the clerics, given time periods, and punishments prescribed.

Firstly, a brief comment on terminology must be made. The statutes speak solemnly of the concubine "concubine”; whereas the source also uses terms such as prostibula, ${ }^{36}$ mulieres suspectis, domestica, ancilla ${ }^{37}$, or in cases of married women uxor, maritata, conthorala. The frequency of the used terms is found in the graph below. It shows that the most commonly used term for addressing women was "concubine" but it must be

31 Ibid, 283.

32 J. V. Polc, Z. Hledíková, Pražské synody, 290.

33 „It is also prescribed to all clerics of whichever status to immediately and without hesitation order their concubines to leave their rectories and neighbourhood under the punishment of excommunication and prison." (translation provided by the author). Ibid., 278.

$34, \ldots$ and so the concubines have to leave the rectories and other people immediately in six days from the notification under the punishment of permanent prison and other prescribed sanctions." (translation by the author). Ibid., 281.

35 Ibid., 283.

36 J. Adámek, Acta correctoris cleri, 50.

37 Ibid., 74. 
noted that the corrector did not usually investigate the background of the women as he focused mainly on the punishment of the clergy. It can still serve as an overlook of the used designation.

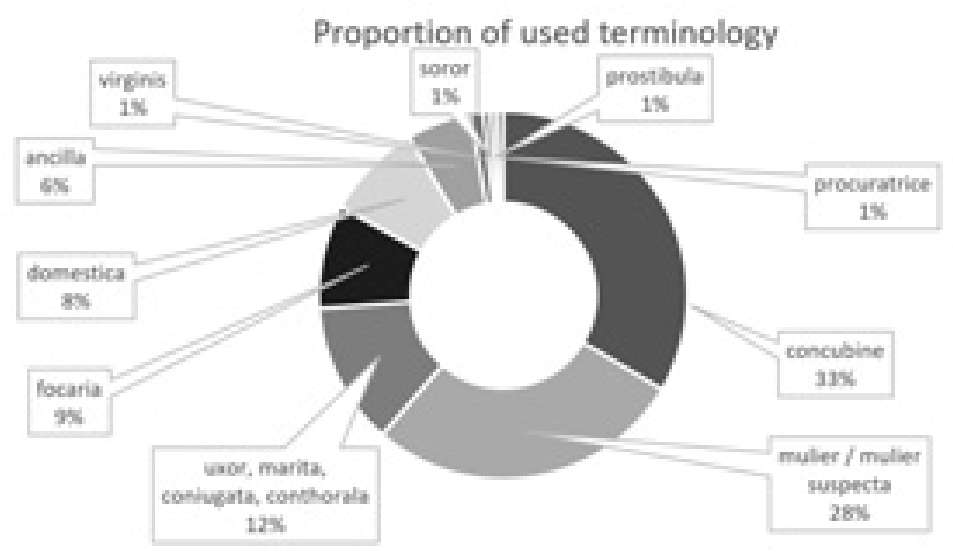

The Acta provides us with some cases which indicate that the corrector sometimes did inquire if the priest had information about the woman i.e. if he knew that the woman was married or a virgin. This leads us to the question if there had been any differences in given punishments with regards to the background of the woman. It can be said that in cases of married women (uxor) or virgins, the punishment was set higher. ${ }^{38}$ To answer the question whether there was a difference in given punishment if the woman was a prostitute or not, one case may serve as an example. In 1408 Henry, parson in Czrhowitz, was asked whether he had any prostitute on his rectory. To this he replied, swearing on the holy gospel, that he did not. The Corrector then asked him if he had any other women. He admitted that he had, and added that he also has children with her. ${ }^{39}$ The source provides other similar examples. ${ }^{40}$ This suggests that there would have been a more severe punishment for those who held concubines, because the priests felt the need to correct the judge and to strongly reject the claim that they were consorting with a prostitute. Surprisingly though, the punishment did not differ. Thus it appears it was just a question of honour.

The example sets ground for the first analysed aspect of the synodical statutes, and that is the question of given punishment. The rule prescribed to all clerics to get rid of their concubine under the sanction of excommu-

$38 \quad$ Ibid., 259.

39 Ibid., 84.

40 Ibid., 31, 40. 
nication, prison or withdrawal of benefice. However, the case law brings a surprising outcome. Apart from two cases, which will be discussed later, the punishments for the breach of celibacy were only conditional. It is thus very rare that the cleric was actually punished (usually in cases of recidivism). One of the cases where the priest was sent straight into prison, ${ }^{41}$ was a case where the Corrector found out that the cleric had a concubine for over seven years and that he had five children with her. ${ }^{42}$ It must be added that although he was imprisoned at the end of April, he was released on the $2^{\text {nd }}$ of May, so the sentence was not very severe. In the second case, the priest got an excommunication sentence, because he was caught with a woman right in church, ${ }^{43}$ which meant a violation of the holy place. He also had to pay for the reordination of the place. ${ }^{44}$ These cases may be considered as severe breaches of the legal rule, but apart from them, the Corrector was rather very benevolent in giving punishments, although the statutes prescribed otherwise.

Even though the sentences were only conditional the excommunication was prescribed only in $5 \%$ of the cases and only $1 \%$ of the clerics received a sentence containing conditional withdrawal of benefice. Most punishments were set to be either prison or a fine (mostly 5 sexagenar$u m^{45}$ grossium). The length of the prison sentence was usually not specified, but when it was, the duration was set between 1 to 3 months - rarely up to a year. The lengths of the jail sentences also cannot be relied upon since clerics rarely completed their sentence. As demonstrated above, they were usually released in a few days. For example, vicar Jan of Lasice is sentenced on the $2^{\text {nd }}$ of August 1413, with the punishment being a fine of 5 sexagenarum grossium and a prison sentence, but he is released the very same day. ${ }^{46}$ Moreover, the conditional excommunication was often prescribed for recidivists, because out of 17 cases that prescribe conditional excommunication, only 6 are interrogated in front of the Corrector for the first time. Besides, the reason for the conditional excommunication sentence was usually a more severe breach of the celibate rule. ${ }^{47}$

41 The prison was right under the archbishop's palace and as is noted in the source, during the mentioned period it underwent reconstruction (sometimes parts of the fines were awareded to the prison keeper for the repairs).

42 J. Adámek, Acta correctoris cleri, 235.

43 The source itself writes „caro in carne erat" indicating a sexual intercourse between the two. Ibid., 36.

44 Ibid.

45 A metric unit used to count currency. One sexagena was equal to approximatley 60 grossium, which was a local currency.

46 J. Adámek, Acta correctoris cleri, 118.

47 One was caught with a woman at a cemetary, or the priest maintained the relationship with the woman for a longer period and had many kids. Ibid., 103. 


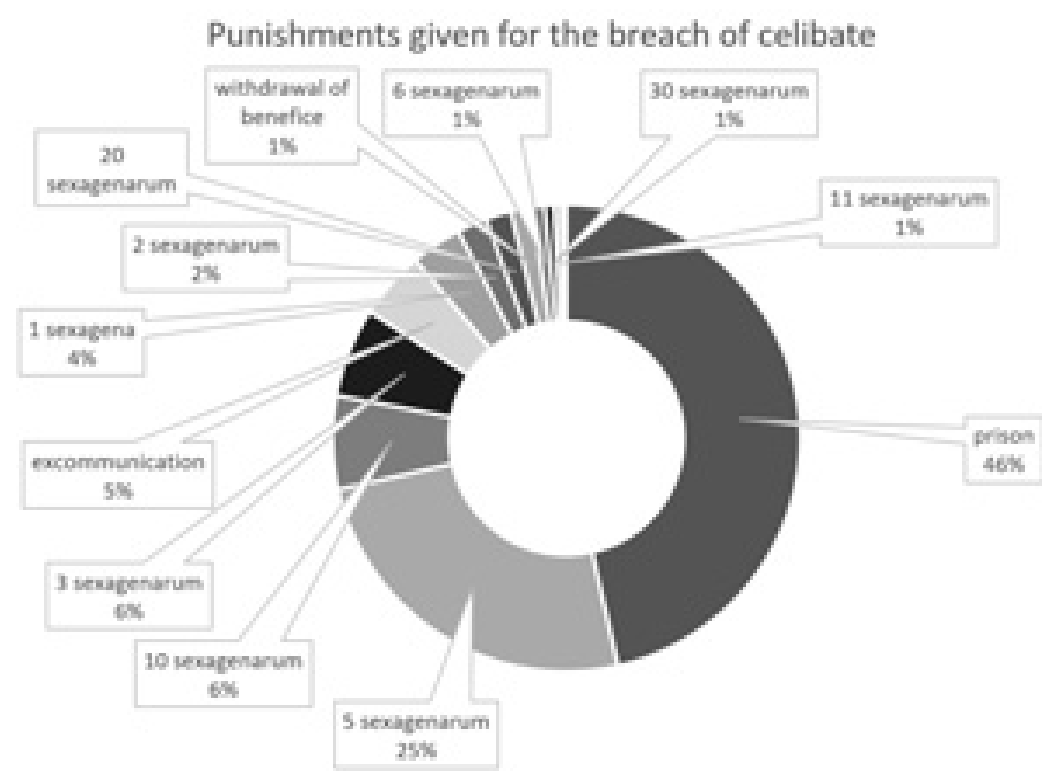

The graph above shows the frequency of given punishments, although it can be deduced that the punishment was not always recorded carefully by the scribe. The sanctions were often combined, meaning the Corrector set a penalty along with a prison sentence. Sometimes the record mentions only fines, but it is possible that the scribe forgot to add the prison sentence. The fine was divided between the prison, the Corrector, or the archbishop and, thus, these values presented in the graph may be more accurate, as the mentioned parties had a material interest in listing them.

Although the punishment was very benevolent, the prescribed fines were quite high, given that only the richest rectories received tithes between 3,6-6,6 sexagenarum grossium per year. ${ }^{48}$ Within the archdeaconries there were only a few rectories that had an income of this value. ${ }^{49} \mathrm{But}$ it occurred only rarely that someone had to actually pay the penalty, and sometimes the priests only paid a part of it. ${ }^{50}$

Another important aspect is the question of recidivism. The exact number of those who were called in front of the judge for a second time is unknown, because apart from the names that are expressly mentioned in various places in the book, there are also cases that suggest recidivism but cannot be conclusively proven. Thus, we will address those that mention a name explicitly in more than one place. These cases provide us also

48 Z. Hledíková, Svět české církve, 60.

49 Ibid., 58-60.

50 J. Adámek, Acta correctoris cleri, 236. 
with a possibility to observe the development of the punishment in time. It would seem that if the priest got caught again, he would receive the punishment prescribed in the first record, as they were only conditional. This, again, was not the regular practice of the judge. Out of 223 cases, 26 are directly determinable recidivists. Only 10 of these receive the punishment that was previously set for them and must pay a fine and serve a prison sentence (although its length is not clear). Not even half of the cases are therefore punished directly. In the rest of the cases the Corrector only sets another conditional punishment when the sanction gets more severe. However, not all the priests received either punishment or a gradation of conditional sanction. For example, on the $9^{\text {th }}$ of March 1407, the Corrector calls priest Bartholomeus of Katušice to testify, for he is questioned for having encounters with a married woman. He is ordered to leave the woman under the punishment of 5 sexagenarum grossium and a one-month prison sentence. He is interrogated again the next year, where he is ordered again "prius in isto libro prescripta irremissibilter solvenda et pena carcerali". ${ }^{51}$ The Corrector did not even raise the sentence and warned him with another conditional punishment, much the same as the previous one. It is not therefore surprising that the priest took the order more as a recommendation and we meet him again for the third time on the $25^{\text {th }}$ of October 1417, when he finally ,incidisse in penas". ${ }^{52}$ In this case, the priest finally receives the sentence the third time he is chastened.

Another aspect mentioned in the synodical statutes is the status of the cleric. The norm says „omnibus clericus cujuscunque status”, suggesting that celibate duty should be enforced on everyone within the clergy. As was already said, celibate duty was set up for higher ordinations during the $13^{\text {th }}$ century, meaning it did not have such a long tradition. In relation to the breach of celibacy, the Acts speak exclusively about priests or clerics whose status cannot be identified. Apart from parsons, the source provides information also on tenants of the rectories. Other ordinations are not mentioned - this is an expected outcome for bishops since they were higher in the hierarchy than the Corrector. The question, however, is this: why does the source not mention any deacons or subdeacons? The book does mention different positions of the priests within their rectory, such as vicars, altar boys, chaplains, etc. One of the more peculiar interrogations is a case of one layperson, who is under the punishment of excommunication and 10 sexagenarum grossium ordered to leave his mistress Cathe-

51 Ibid., 66. The punishment is set to be the same as was previously recorded in the book.

52 Suggesting the priest received the punishment prescribed. J. Adámek, Acta correctoris cleri, XVI. 
rine and go back to his wife. ${ }^{53}$ Adultery was considered illegal ${ }^{54}$ as well as bigamy, ${ }^{55}$ according to canon law. But it is interesting that this case was judged by the Corrector, because the marriage of lay people fell within the scope of the officials. ${ }^{56}$ In comparison to the other punishments given, this layperson received quite a severe sanction. Apart from this rarity, the source does not suggest any difference between punishments regarding the position of the priest. In $67 \%$ of the cases the source speaks about parsons, in $13 \%$ of priests, $9 \%$ mention tenants, $8 \%$ vicars and the rest speak of chaplains, altar boys or clerics.

The last question is that of time periods. The general legal rule set by the synodical statutes prescribed to clerics to get rid of the woman in six days under the punishment of prison and other sanctions. ${ }^{57}$ Only 49 cases explicitly mention the period and the most common interval is one month $(33 \%)$. In $32 \%$ of the cases, the Corrector orders the cleric to get rid of the woman between the $7^{\text {th }}$ and the $23^{\text {rd }}$ day, and the third most common time was set to 2 months (21\%). In $8 \%$ of the cases, the given time surpasses 3 months. The Corrector followed the norm only in two cases, when the time had been set to less than 6 days. ${ }^{58}$ Usually the period starts from "hinc" (now) and the end of it is bound to a feast day. The given time periods reflected the distance of the rectory from Prague.

It is inconclusive what the period for those cases that did not bear any set duration was. One of the possibilities is that they followed the prescribed norm of the statutes, meaning they had been set for less than 6 days. This would mean it must have been a custom, so the scribe would not have felt the need to record such a detail, but given the other circumstances, it is more likely the scribe just forgot to list the time or the time was simply not given.

As to the overall number of cases, in the year 1407 the Corrector investigated $66(1)^{59}$ cases connected to concubinage (54,09\%). In 1408 the number was 70 (14) out of 188 (37,23\%); in 1409 it was 50 (5) out of 112 $(41,66 \%)$, and in the year 1410 the investigation was carried out in 16 (4) out of 76 cases $-21,05 \%$. The overview counts recidivism and cases that only point out the link to concubinage, but the record is not finished, so the outcome of the cases is quite not clear.

53 Ibid., 65.

54 J. A. Brundage, Law, Sex, 247.

55 P. Hinschius, System des Katolischen Kirchenrechts, 170.

56 Originally also within the scope of archdeacons. B. Kubíčková, K počátkưm oficialá$t u, 28$.

57 J. V. Polc, Z. Hledíková, Pražské synody, 281.

58 J. Adámek, Acta correctoris cleri, 63, 120.

59 The second number concerns the case of recedivism. 


\subsection{Games, taverns and disorderly conduct}

Other types of moral delicts and offences present within the Acts were the illegal playing of dice, visiting taverns and brothels, and possibly some other disorderly conduct. The prohibition of these was mentioned in one of the synodical statutes proclaimed by the archbishop on the $15^{\text {th }}$ of June 1404, when he orders a punishment of excommunication and prison for those that would play games, visit taverns, attend tournaments or hunts. ${ }^{60}$ The prohibition is later repeated on the $18^{\text {th }}$ of October 1406, when the punishment is set to be permanent prison „et aliis penis in statutis promulgatis." 61

The source mentions $26(33)^{62}$ names that are ordered by the Corrector to cease with such behaviour. The majority of these cases are a concurrence of acts, and thus, apart from visiting taverns, the clerics are also often warned not to visit brothels (12 cases). Same as in the case of concubinage, the punishments were conditional and set much lower than the prescribed norm. Conditional excommunication was only received in two cases. The first of them is a case of a priest, who apart from breaching the norm for playing the dice also infringed the rule regarding his celibate duty. ${ }^{63}$ When he did not follow the order of the Corrector for the first time and once again appeared in front of the judge, the source comments that he received his punishment "in actis Herssonis de anno domini MCCCCVI". ${ }^{64}$ But the first punishment of excommunication was dated to the year 1408, which means that if the scribe did not make a mistake, the cleric was a recidivist. So, although we meet him for the first time in 1408, he already had a history of appearing before the judge. The second case which received conditional excommunication was the case of Nicolaus of Údrnice ${ }^{65}$ who was also charged with attack on vicar John Chromý. ${ }^{66}$ Just like in the cases regarding the breach of celibacy, the conditional excommunication was given either to recidivists or for more severe breaches of the norm (such as different types of concurrences).

60 „Item mandat, ne clerici curati et non curati, vicarii, altariste thabernas visitent, ne coreis aut torneamentis nec ludis taxillorum insistant, nec venacionibus cum canibus et omnibus levititatibus sub pena carcerali et excommunicationis." In: J. V. Polc, Z. Hledíková, Pražské synody, 271-272.

61 Ibid., 281.

62 If the recidivism is counted. This forms less than $5 \%$ of the overal criminal cases dealt with in front of the Corrector. Robert Vlk arrives at a different number in his article, mentioning the frequency of these acts to be around 10\%, more in: Robert Vlk, „Clerus ludens et bibens”, Časopis Matice moravské 2/2020, 318.

63 J. Adámek, Acta correctoris cleri, 121.

64 In the Acts of the Corrector Herssonus dated 1407. Ibid.

65 A. Podlaha, Akta korektorů duchovenstva, 32.

66 J. Adámek, Acta correctoris cleri, 143. 
The most common punishment was the punishment of prison (see graph below) either with a fine (5 sexagenarum grossium) or without (22\%). In four cases the clerics were imprisoned before the trial, although it is not quite clear how long they spent in prison, and neither are the details of the imprisonment.

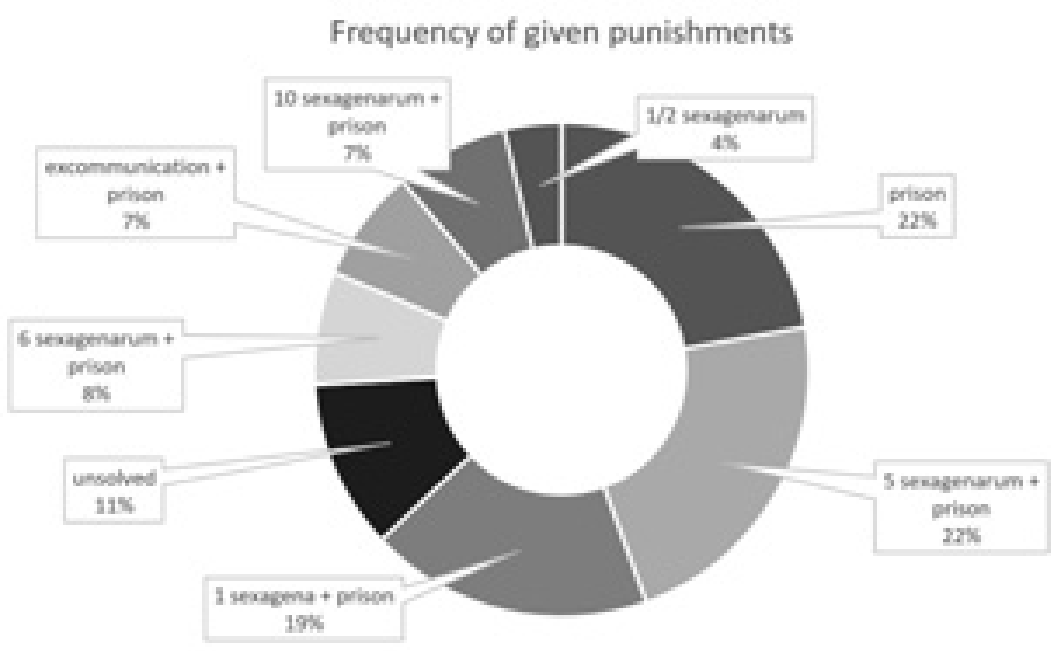

The form of the punishment and its realization followed the prescribed scheme, meaning the sanction was not very severe and the Corrector, again, did not follow the rules prescribed by the synods. One of the last things worth mentioning is the case of Jacob of Slaná, which points to the overall benevolence of the institution. On the $7^{\text {th }}$ of April, Jacob comes in front of the judge drunk and is thus immediately sent to prison. He is released the very next day and ordered not to play dice under the punishment of prison (although the prescribed norm was excommunication). Nevertheless, he is interrogated again in August of the same year, when he is asked if he committed any theft, visited any brothels, or played games in the taverns. He denies the former but confesses to the rest. One would expect that the Corrector would sentence him to prison, since that was the conditional punishment for his first transgression; instead, the judge releases him with yet another conditional sanction of prison. The years go by, and he is investigated again in 1413, after his release from prison (the circumstances of the imprisonment are not clear) and warned not to indulge further in any suspicious behaviour. He is interrogated again a month later, when he receives a conditional punishment of 3 months in prison and a fine of 1 sexagena grossium. The punishment is affirmed 
in 1415, when he is interrogated for the fifth time. The last and sixth encounter he makes with the Corrector is in May of 1415, when he is warned again and finally receives a punishment of excommunication. Which is only conditional. ${ }^{67}$ It is not clear if he corrected his behaviour or died, since the source does not mention his name again.

To draw a comparison to secular provisions regarding the same transgressions, there is a legal rule included in Maiestas Carolina ${ }^{68}$ where the source prohibits playing dice and the King orders that any debts or obligations arising from such conduct is not enforceable. The one who loses is not obliged to fulfil the obligation. ${ }^{69}$ The next Article specifies that the prohibition applies to an amount higher than 1 sexagena grossium. Both participants have a duty to submit the fine or fall into King's disfavour. ${ }^{70}$ The non-enforcement of the obligation is also mentioned in municipal law, ${ }^{71}$ which adds a corrective regarding cheating during the game - in such cases the cheater would lose his thumb. ${ }^{72}$

In comparison with playing games in the tavern, the Acts do not mention many cases of other disorderly conduct. The judicial book mentions four cases that name such behaviour. In two of them the accused were parsons, two were vicars. The punishments were set between 1-5 sexagenarum grossium, combined with a prison sentence (1-3 months). The transgressions were, for example, the illegal burning of thatch, ${ }^{73}$ dancing ${ }^{74}$ or singing ${ }^{75}$ in public, upsetting citizens with vulgarisms, ${ }^{76}$ disturbance of public order, ${ }^{77}$ or practicing witchcraft. ${ }^{78}$

One of the charged subjects was accused of denigrating the previous parson, when during a service for the soul of the deceased priest he proclaimed that he hoped the soul of his predecessor would be torn apart in hell. ${ }^{79}$ This vicar was inter alia also charged with disclosure of confessions

67 Ibid., 29.

68 Hermenegild Jireček, Codex iuris Bohemici. Praha 1976, 131-132.

69 Ibid., 135.

70 Ibid., 133.

71 Miroslav Flodr, Právní kniha města Brna z poloviny 14. století, Archiv města Brna, Brno 1990, 306.

72 M Ibid., 333.

73 J. Adámek, Acta correctoris cleri, 24.

74 Ibid., 24.

75 Ibid., 25.

76 Ibid., 102.

77 Ibid., 24.

78 Ibid., 80.

79 Ibid., 128. 
and carrying weapons. The latter was prohibited within the Liber Tertius of Liber extravagantium decretalium, ${ }^{80}$ where it is forbidden under the punishment of excommunication. ${ }^{81}$ The vicar denied all allegations and thus, the Corrector orders further investigation. Unfortunately, the book does not provide any other information regarding this name and thus it cannot be concluded what the punishment would have been. ${ }^{82}$ The source does, however, provide another case of carrying weapons. Nicolaus of Obora receives a punishment of 10 sexagenarum grossium for the crime (this fine is later altered to 5 sexagenarum). He is also warned not to have any women, visit any taverns, and carry any balistam ${ }^{83}$ under the punishment of 10 sexagenarum and one year in prison. ${ }^{84}$ The overall tendency of benevolent punishment prevails within cases of breaches of other moral duties as well.

\section{CONCLUSION}

The Acta correctoris cleri provide a brief insight into the agenda of a unique institution that had no equivalent within medieval Europe. The original idea behind the creation of the office might have been genuine interest in correcting the clergy but at the beginning of the $15^{\text {th }}$ century, as demonstrated, the reality did not match the prescribed ideals. The Corrector endeavoured to investigate the cases, to call the clerics to Prague and warn them about the breach of the norm, but the enforcement of the legal rules was not as efficient.

It must be noted that had the Corrector followed the prescribed punishment and excommunicated over two hundred priests (given that the Prague diocese had over two thousand rectories ${ }^{85}$ at the beginning of the $15^{\text {th }}$ century) the constant change could lead to destabilization of the administrative units. Moreover, in some of the peripheral parts of the diocese, celibate duty was not as rooted as in the central parts, ${ }^{86}$ and its enforcement was gradual up until the $16^{\text {th }}$ century. ${ }^{87}$ This can also be seen

80 Emil Friedberg, Corpus iuris Canonici, Akademische Druck - U. Verlagsanstalt, Gratz 1959, 450.

81 Ibid., 450.

82 J. Adámek, Acta correctoris cleri, 128.

83 It cannot be said for sure if the correct translation would be a bow, a slingshot or a crossbow.

84 J. Adámek, Acta correctoris cleri, 157, 236.

85 Z. Hledíková, Svět české středověké církve, 62. Although it can be estimated that the number was much higher.

86 Zdeňka Hledíková, Úpadek nebo růst? K situaci církve v Čechách ve 14. století, Tradition et Cultus. Miscellanea historica bohemica Miloslao Vlk, archiepiscopo Pragensi, ab eis amicisque ad annum sexagesium dedicata, Karolinum, Prague 1993, 61.

87 Ibid., 61. 
as an explanation of why the Corrector did not sentence the priests to the prescribed punishments straight away. The intention behind his benevolence towards those who played dice in taverns is much less clear, because there was a possibility that they could lose the Church's property, and this constituted more of a threat than having a concubine. The lack of severe consistency may also be the reflection of a decay of ecclesiastical moral or ideological standards that began during the $14^{\text {th }}$ century, and not only in Bohemia. ${ }^{88}$ On the other hand, the question of whether the preserved source really portrays the ultimate decline of morality amongst the clergy, or the celibate duty was never thoroughly executed, remains. If we look back at the only detailed visitation protocol, ${ }^{89}$ we find that every deaconry among Prague's archdeaconry registered occurrences of breach of moral duties, especially breach of celibacy, and not to a negligible extent. Within the Registrum obligationum the protocol contains one record, consisting of a mandate from a Corrector Wozslaus, ordering a priest from Chrast to avoid encounters with women, under the punishment of prison, a fine, and privation of his benefice..$^{90}$ Other mandates are issued by the archdeacon himself, containing penalties mainly for the breach of celibate duty. These consist mainly of fines. ${ }^{91}$ This suggests that the punishments for moral delicts were not very severe in the previous period either, although the Registrum does not provide a lot of representative convictions. It may imply, however, that Acta correctoris cleri is not an exceptional case of the Church's leniency.

The graph below shows the agenda of the Corrector between 1407 and 1410 and the proportionality of cases dealt in front of the judge. As is shown, the majority of cases were moral delicts, which is why the paper chose to analyse these transgressions. The benevolence of the judge was not much different regarding the criminal cases. Although the Corrector did send the gravest cases straight to prison, pillory or potentially excommunicated them from the Diocese, the book is also full of pardons received from the Corrector or the archbishop. ${ }^{92}$ It remains unclear why the criminals were pardoned, especially by the archbishop himself, who, as mentioned above, in 1407 threatened every archdeacon who would not submit the visitation Acts, unravelling the misconduct of ecclesiastical administration, with excommunication. Receiving a prison sentence for

88 Jiří Spěváček, Václav IV., Svoboda, Praha, 1986, 222.

89 See fn. 26.

90 I. Hlaváček, Z. Hledíková, Vizitační protocol, 380.

91 Ibid., 380-403.

92 It cannot be clearly determined what the reasoning behind all of the pardons was, or what exact influence the archbishop had over the Corrector's judicial praxis. It is clear that the archbishop did intervene in some cases, but it remains unclear why. 
murder was an exceedingly meek punishment, given that the punishment in secular law was death. ${ }^{93}$

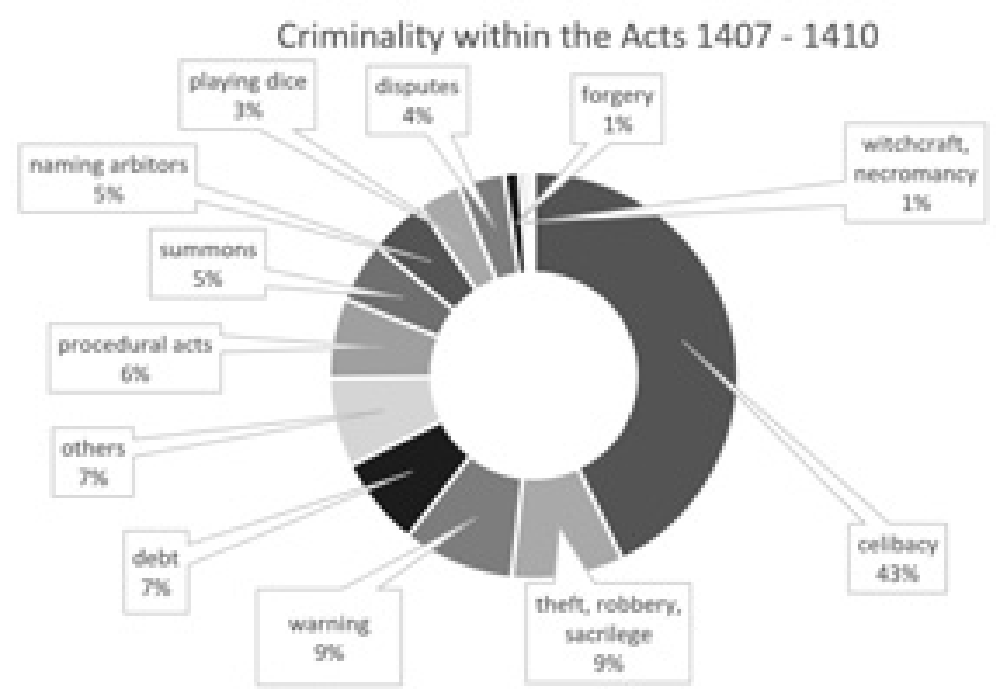

Although only the moral delicts were addressed, Acta provides us with other cases investigated as breaches of canon law, especially the criminal agenda, which makes up app. $9 \%$ of the overall records. As the book served sort of as a public register for the clergy, many records depict different procedural acts such as summons, admonition, call for naming additional evidence, etc.

Nevertheless, the source provides a valuable insight into the ecclesial administrative structure at the beginning of the $15^{\text {th }}$ century. The records of all the cases have a similar structure and do not provide many details on individual cases, meaning the source does not provide a direct explanation of the paroles given by the Corrector or the archbishop, and thus serves mainly as a glance on the plurality of cases.

\section{BIBLIOGRAPHY}

Jan Adámek, Korektor kléru arcidiecéze pražské jako trestní soudce. Sacri canones servandi sunt, Historický ústav AV ČR, Praha 2008.

Jan Adámek, Archiv český díl XLIII. Acta correctoris cleri civitatis et diocesis Pragensis annis 1407-1410 comparata, Centrum medivistických studií, Praha 2018.

93 J. Adámek, Acta correctoris cleri, 72. 
James A. Brundage, Law, Sex, and Christian Society in Medieval Europe, The University of Chicago Press, Chicago - London 1987.

Miroslav Flodr, Právní kniha města Brna z poloviny 14. století, Archiv města Brna, Brno 1990.

Paul Fournier, Les officialités au Moyen Age. Étude sur l'organisation, la competénce et la competénce de tribunaux ecclésiastiques ordinaire en France de 1180 a 1328, Paris 1880.

Emil Friedberg, Corpus iuris Canonici, Gratz 1959.

Peter Herde, Römisches und Kanonisches Recht Bei der Verfolgung des Fälschungdelikts im Mittelalter, Cambridge University Press, Cambridge 1965.

Paul Hinschius, System des Katholischen Kirchenrechts mit besonderer Rücksicht auf Deutschland, Berlin 1895.

Ivan Hlaváček, Zdeňka Hledíková, Vizitační protokol pražského arcijáhenství pražského arcijáhna Pavla $z$ Janovic z let 1379-1382, Akademia, Praha, 1973.

Zdeňka Hledíková, Korektoři kléru pražské diecéze, Právněhistorické studie 16, Academia, Praha 1971.

Zdeňka Hledíková, Úřad generálních vikářu pražského arcibiskupa v době předhusitské, Praha 1971.

Zdeňka Hledíková, Svět české středověké církve, Argo, Praha 2010.

Hermenegild Jireček, Codex iuris Bohemici, Praha 1870.

Jiří Kejǔ, Výbor rozprav a studií z kodikologie a právníh dějin, Masarykův ústav a Archiv Akademie věd, Praha, 2012.

Božena Kubíčková-Čádová, K počátkům pražského oficialátu, Sborník př́íspěvků $k$ dějinám hlavního města Prahy 5, Praha 1932.

Alexander Patschowsky, Die Anfange einer ständigen Inquisition in Böhmen, Walter de Gruyter, Berlin - New York 1975.

Antonín Podlaha, Akta korektorů duchovenstva diecéze pražské z let 1407-1410, Sumptibus S. F. Capituli Metropolitani Pragensis, Praha 1921.

Jaroslav V. Polc, Zdeňka Hledíková, Pražské synody a koncily předhusitské doby, Karolinum, Praha 2002.

Jiří Spěváček, Václav IV., Svoboda, Praha, 1986.

Robert Vlk, „Clerus ludens et bibens”, Časopis Matice moravské 2/2020, 303-323. 


\title{
Вероника ОНДРАШКОВА*
}

\author{
ПРАВНИ АСПЕКТИ УЛОГЕ НАДЗОРНИКА \\ СВЕШТЕНСТВА У ПРАШКОЈ ДИЈЕЦЕЗИ \\ С ПОЧЕТКА 15. ВЕКА
}

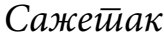

Апстракт: Један од кључних периода за еволуцију средњевековне административне црквене структуре у Краљевству Бохемије био је 14. век. Овај период поставља темељ великом броју напредних установа и бироа у оквиру црквене администрације. Један од њих био је Надзорник свештенства. Оснивање службе датира око половине 14. века и, иако је представљало покушај цркве да стави на снагу статуте представљене на синодима, разлог оснивања треба тражити и у политичким тежњама првог прашког надбискупа. Corrector cleri civitatis et diocesis Pragensis службовао је само у Прашкој дијецези и био јединствена институција у границама средњевековне Европе, будући да није заживео у другим регијама. Надзорник свештенства био је институција слична кривичном судији, чији је задатак такође било истраживање и проматрање моралности свештенства, те и, уколико се икакве сумње у понашање свештеника роде, спровођење испитивања и евентуално одређивање казне.

Овај рад анализира Acta correctoris cleri из 1407-1410, једини свеобухватни сачувани извор који предочава рад Надзорника у оквиру Прашке дијецезе. Због свог значаја, извор је био предмет различитих анализа у прошлости, те ће аутор покушати да у овом раду приђе предмету из правне перспективе. Прво ће направити везу између писаног и обичајног права, показујући, кроз изводе из статута синода, каква је требало да буде поправна мера. Затим, предвиђена поправна мера ће бити упоређена са судском праксом надзорникове канцеларије, одражавајући стварност. Већина покренутих случајева тиче се кршења дужности целибата, али извор прилаже и случајеве светогрђа, крађе, убиства или просто учествовања у нечасним понашањима попут коцкања или посећивања локалних крчми. Махом је у рукама архиђакона било да таква девијантна понашања пријаве Надзорнику, који би поступак започео позивањем свештеника у Праг, испитивањем и одређивањем могуће казне. Испитивање би, у неким другим случајевима, могли да иницирају други свештеници који су начелно морали да пријаве било какво сумњиво понашање, иако је то могло да послужи као скретање пажње с

* Мастер студент у 6. семестру, Правни факултет Масариковог Универзитета, Чешка република veronikaondraskova3gmail.com

Рад је део студентског истраживачког пројекта.

Рад је изложен на конференцији „Iustoria 2021: Право и религија” која је одржана на Правном факултету Универзитета у Београду од 25. до 27. марта 2021. године. 
испитивања њих самих - када би их Надзорник упитао јесу ли имали икакву жену из парохије, понекад су одговарали „Кунем се Библијом да нисам, али мислим да суседни свештеник јесте."

Циљ овог рада, стога, јесте да скрене пажњу на различите видове кажњавања које је одређивао Надзорник свештеника; њихов карактер, временски период који је дат за поправљање свештениковог понашања, и на могућу везу статуса свештеника с добијеном санкцијом. Рад се фокусира на моралне деликте јер су они чинили већину случајева који су долазили пред суд; такође предочава благост кажњавања уопште, а нарочито по питању рецидивизма.

Кључне речи: Наgзорник свешиченстива. - Прашка gијецеза. - Црквени суgија. - Земле Бохемијске круне. - Морални деликйи. 